\title{
Prevalence of childhood psychiatric disorders may be underestimated
}

Costello EJ, Mustillo S, Erkanli A, et al. Prevalence and development of psychiatric disorders in childhood and adolescence. Arch Gen Psychiatry 2003;60:837-44.

\section{What is the prevalence of psychiatric disorders among children and adolescents?}

\section{METHODS}

Design: Prospective cohort study.

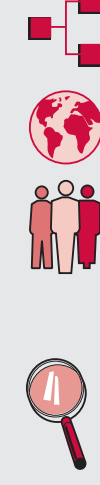

Setting: 11 counties in North Carolina, USA; interviews 19932000

ofe Population: 1420 children aged 9, 11, or 13 years at intake. Parents completed a screening questionnaire (based on the Child Behaviour Checklist). Children scoring above a preselected cut off on the questionnaire, plus 1 in 10 randomly selected children below the cut off, and all American Indian children screened, irrespective of score, were recruited for further interviews.

Analysis: Child and parent were interviewed separately on a yearly basis, using the Child and Adolescent Psychiatric Assessment (CAPA, records details of symptoms seen in the past 3 months). A symptom was considered present if reported by either parent or child or both. Data from the CAPA were used to generate DSM-IV diagnoses. Population prevalence estimates were calculated using weighting to correct for each participant's likelihood of selection.

Outcomes: Presence of DSM-IV diagnoses; prevalence of DSMIV disorders.

$\square \square$ Follow up period: Three to 7 years, until age 16

Table Three month prevalence of selected DSM-IV diagnoses (all age groups)

\begin{tabular}{|c|c|c|c|}
\hline Diagnosis & $\begin{array}{l}\text { Percentage of } \\
\text { participants } \\
\text { with disorder } \\
(95 \% \mathrm{Cl})\end{array}$ & $\begin{array}{l}\text { Percentage of } \\
\text { boys with } \\
\text { disorder } \\
(95 \% \mathrm{CI})\end{array}$ & $\begin{array}{l}\text { Percentage of } \\
\text { girls with } \\
\text { disorder } \\
(95 \% \mathrm{Cl})\end{array}$ \\
\hline Any diagnosis & $\begin{array}{l}13.3 \\
(11.7 \text { to } 15.0)\end{array}$ & $\begin{array}{l}15.8 \\
(13.5 \text { to } 18.5)\end{array}$ & $\begin{array}{l}10.6 \\
(8.7 \text { to } 12.9)\end{array}$ \\
\hline $\begin{array}{l}\text { Any behavioural } \\
\text { disorder }\end{array}$ & $7.0(6.0$ to 8.2$)$ & 9.5 (7.9 to 11.5 ) & $5) 4.5$ (3.5 to 5.7 ) \\
\hline $\begin{array}{l}\text { Serious emotional } \\
\text { disturbance }\end{array}$ & $6.8(5.8$ to 7.9$)$ & 7.9 (6.5 to 9.5$)$ & 5.6 (4.3 to 7.3 ) \\
\hline $\begin{array}{l}\text { Oppositional } \\
\text { defiant disorder }\end{array}$ & 2.7 (2.2 to 3.3 ) & 3.1 (2.4 to 4.2 ) & 2.1 (1.6 to 2.9 ) \\
\hline Conduct disorder & 2.7 (2.1 to 3.5$)$ & 4.2 (3.1 to 5.6$)$ & $1.2(0.7$. to 2.1$)$ \\
\hline Any anxiety disorder & $2.4(1.8$ to 3.1$)$ & $2.0(1.3$ to 3.1$)$ & 2.9 (2.0 to 4.0 ) \\
\hline $\begin{array}{l}\text { Substance use } \\
\text { disorders }\end{array}$ & $2.4(1.8$ to 3.1$)$ & $2.8(1.9$ to 4.0$)$ & 2.0 (1.3 to 2.9$)$ \\
\hline $\begin{array}{l}\text { Any depressive } \\
\text { disorder }\end{array}$ & $2.2(1.6$ to 3.0$)$ & 1.6 (1.0 to 2.5$)$ & 2.8 (1.8 to 4.3 ) \\
\hline ADHD & $0.9(0.6$ to 1.2$)$ & 1.5 (1.0 to 2.1$)$ & 0.3 (0.2 to 0.5$)$ \\
\hline
\end{tabular}

For correspondence: E J Costello, Center for Developmental Epidemiööör. Department of Psychiatry and Behavioural Sciences, Duke University Medical School, Durham, North Carolina, USA; jcostell@psych.mc.duke.edu

Sources of funding: National Institutes of Health, Bethesda and the William T Grant Foundation, New York.

\section{MAIN RESULTS}

The average three month prevalence of DSM-IV disorders was 13.3\% in children aged 9-16 years (see table 1). By 16 years, 36.7\% of children had been diagnosed with at least one DSM-IV disorder. Children with a previous DSM-IV disorder were significantly more likely than those without a previous disorder to have a subsequent DSM-IV diagnosis (AR 28.0\% with previous diagnosis $v 9.3 \%$ without previous diagnosis; OR 3.7, $95 \%$ CI 2.9 to 4.9 ).

\section{CONCLUSIONS}

The cumulative prevalence of psychiatric disorders in children by age 16 is greater than that suggested by cross sectional studies. A previous psychiatric disorder increases the likelihood of subsequent psychiatric diagnosis.

\section{NOTES}

Not all children were interviewed in each year due to funding constraints. Of the total possible interviews, $84 \%$ were completed.

\section{Commentary}

7 his is a time of riches for those interested in the epidemiology of psychiatric disorders in childhood and adolescence. In this paper Costello and colleagues present data from the Great Smoky Mountains Study in the United States. We have also recently seen data from large epidemiological studies in New Zealand' and Great Britain. ${ }^{2}$ This study provides an important longitudinal perspective on the changes in psychiatric presentation from age 9-16 years. It is particularly interesting in the way in which it examines comorbidity and continuity of disorders across time. It is conducted in a predominantly rural, white area of America, but there is some overlap between the findings of this study and others, suggesting that the findings may generalise to other settings.

Three findings in particular catch the eye. Firstly, the relatively low levels of Attention Deficit Hyperactivity Disorder (ADHD) found $10.9 \%$ across this age range). Secondly, the high level of comorbidityparticularly between depression and anxiety-is striking, as is the high level of continuity of disorder (homotypic continuity), and between disorders (heterotypic continuity), over time, again particularly between depression and anxiety. Finally, girls seem particularly at risk of continuing psychiatric disorder once they have developed one, and at higher risk of developing another psychiatric disorder. This finding in particular represents a challenge to clinical practice-that although girls have a lower risk of psychiatric disorder overall, when they do develop a disorder it seems that they should be considered at special risk of further disorder. When these findings are considered, together with those from New Zealand, ${ }^{1}$ an important public health message emerges. The roots of much adolescent (and adult) psychiatric disorder begin in childhood, with psychiatric disorder in younger years carrying a significant risk for adverse psychiatric outcomes throughout life.

Paul Ramchandani MSc MRCPsych Section of Child and Adolescent Psychiatry, University of Oxford Department of Psychiatry, Oxford, UK

1 Kim-Cohen J, Caspi A, Moffitt TE, et al. Prior juvenile diagnoses in adults with mental disorder: developmental follow-back of a prospectivelongitudinal cohort. Arch Gen Psychiatry 2003;60:709-17

2 Ford T, Goodman R, Meltzer H. The British Child and Adolescent Mental Health Survey 1999: The prevalence of DSM-IV Disorders. J Am Child Adolesc Psychiatry 2003;42:1203-11. 